CZASOPISMO INŻYNIERII LA¿OWEJ, ŚRODOWISKA I ARCHITEKTURY JOURNAL OF CIVIL ENGINEERING, ENVIRONMENT AND ARCHITECTURE

JCEEA, t. XXXIV, z. 64 (2/II/17), kwiecień-czerwiec 2017, s. 227-234, DOI:10.7862/rb.2017.94

Jadwiga BIZON-GÓRECKA ${ }^{1}$

Michał MATUSZCZAK ${ }^{2}$

\title{
ANALIZA TECHNOLOGICZNOŚCI ROZWIĄZAŃ PROJEKTOWYCH OBIEKTÓW BUDOWLANYCH O KONSTRUKCJI STALOWEJ
}

\begin{abstract}
Celem artykułu jest wskazanie możliwości oceny jakości rozwiązań konstrukcyjno-materiałowych poprzez analizę ich technologiczności, formułowanej też jako jakość technologiczna. Pojęcie technologiczności obiektu budowlanego zdefiniowano jako przystosowanie zastosowanych rozwiązań do łatwego i uzasadnionego ekonomicznie wykonania, zapewniającego spełnienie wymagań stawianych obiektowi w całym cyklu jego życia. Cykl życia obiektu budowlanego rozpoczyna artykułowanie potrzeb budowlanych, następnie pojawia się koncepcja i studium wykonalności przedsięwzięcia, po czym występuje projektowanie obiektu i procesów wykonawczych. Kolejne fazy cyklu życia obiektu to realizacja procesów logistycznych i budowlanych, które kończy oddanie do użytkowania. Dalej rozpoczyna się eksploatacja zakończona likwidacją. Podjęto próbę specyfikacji kryteriów oceny jakości technologicznej obiektów wznoszonych w konstrukcji stalowej z uwzględnieniem poszczególnych faz cyklu istnienia obiektów. Dociekania przeprowadzono na podstawie dostępnej literatury oraz praktycznych doświadczeń autorów opracowania. Wskazano potrzebę rozważań konstrukcyjno-materiałowych i metody wznoszenia obiektu jako grupy kryteriów ogólnych. Podkreślono, niezauważaną dotychczas, konieczność uwzględnienia w ocenie technologiczności perspektywy podmiotowej. Wynika to ze specyficznych wymagań stawianych obiektom budowlanym przez poszczególnych interesariuszy budowlanych projektów inwestycyjnych. Z uwagi na fakt, że procesy kształtowania obiektu w fazie programowej, projektowej i realizacyjnej są związane z procesami eksploatacyjnymi i fazą likwidacyjną, podkreślono, że każdy z interesariuszy winien postrzegać wszystkie etapy cyklu życia obiektu.
\end{abstract}

Słowa kluczowe: konstrukcje stalowe, jakość technologiczna, cykl życia obiektu

\footnotetext{
${ }^{1}$ Autor do korespondencji / corresponding author: Jadwiga Bizon-Górecka, Uniwersytet TechnologicznoPrzyrodniczy, al. prof. S. Kaliskiego 7, 85-796 Bydgoszcz, tel. +48 501637 067, e-mail: bizon@utp.edu.pl

2 Michał Matuszczak, Firma Gotowski Budownictwo Komunikacyjne i Przemysłowe Sp. z o.o., ul. Toruńska 300, 85-880 Bydgoszcz, tel.+48 605760171, e-mail: m.matuszczak1975@gmail.com
} 


\section{Wprowadzenie}

Problemy technologiczności opisywali m.in. Sadowski [7] i Jaworski [5]. Zagadnieniem technologiczności $\mathrm{w}$ odniesieniu do budowlanych konstrukcji stalowych zajmowali się między innymi Augustyn i Śledziewski [1].

Technologiczność rozwiązań budowlanych oznacza zespół cech określających możliwość łatwego i efektywnego wykonania obiektu budowlanego, jego ustrojów, elementów i wyrobów - w danych warunkach produkcyjnych - bez szkody dla rozwiązań funkcji, konstrukcji, walorów użytkowych i estetycznych. Musi uwzględniać wymagania wynikające $\mathrm{z}$ danego poziomu technicznoorganizacyjnego realizacji procesów budowlanych. Czynniki określające jakość technologiczną rozwiązań projektowych to wymagania technologiczności rozwiązań budowlanych [5].

Ocena jakości technologicznej rozwiązań budowlanych musi uwzględniać specyfikę branży budowlanej. Cechy specyficzne działalności budowlanej można rozpatrywać podejściem: przedmiotowym (poprzez analizę cech produktów branży i ocenę ich wpływu na działalność budowlaną) oraz podmiotowym (poprzez rozważania roli i znaczenia interesariuszy przedsięwzięć budowlanych).

Obiekty budowlane, jako efekty produkcji budowlanej, mogą być wznoszone według różnych rozwiązań konstrukcyjno-materiałowych i przy zastosowaniu wybranych metod realizacyjnych.

W ostatnich latach coraz większą popularność zdobywają konstrukcje stalowe. Wynika to $\mathrm{z}$ wielu zalet stosowania stali $\mathrm{w}$ budownictwie. Jedną $\mathrm{z}$ nich (najczęściej najważniejszą) jest niska cena. Uzyskuje się ją w wyniku ciągłego zmniejszania ilości stali w wykonywanych elementach konstrukcyjnych. Niska cena takich inwestycji wynika $\mathrm{z}$ faktu, że w przeciągu ostatnich lat dokonał się olbrzymi postęp technologiczny obróbki stali. Konstrukcje z kształtowników giętych na zimno są idealnym materiałem do budowania ścian działowych oraz nośnych konstrukcji głównych hal stalowych. Stosowanie coraz cieńszej blachy stalowej, jako materiału wyjściowego do produkcji belek, ilość niezbędnej do produkcji stali zmniejsza się, co przekłada się na tak pożądany przez inwestorów spadek ceny.

Kolejną zaletą jest szybki i stosunkowo prosty proces montażu obiektów o konstrukcji stalowej z dostarczonych przez producenta stalowych prefabrykatów.

Może się to odbywać w krótkim czasie tylko dzięki łączeniu modułów - gotowych, stale powtarzających się w konstrukcji elementów, wcześniej przygotowanych przez producenta. Zadaniem montażystów jest odpowiednie połączenie wszystkich elementów w scaloną konstrukcję hali stalowej.

Powyższe zalety konstrukcji stalowych decydują w głównej mierze o tak wielkiej i stale rosnącej popularności stali, jako materiału budowlanego.

Zauważyć trzeba, że w projektach inwestycyjno-budowlanych uczestniczy szereg interesariuszy, wchodzących w relacje z przedmiotem przedsięwzięcia, tj. obiektem budowlanym na różnych etapach jego cyklu życia. 


\section{Cykl życia obiektu budowlanego a interesariusze projektu}

Sekwencyjną postać cyklu życia obiektu budowlanego pokazuje rysunek 1.

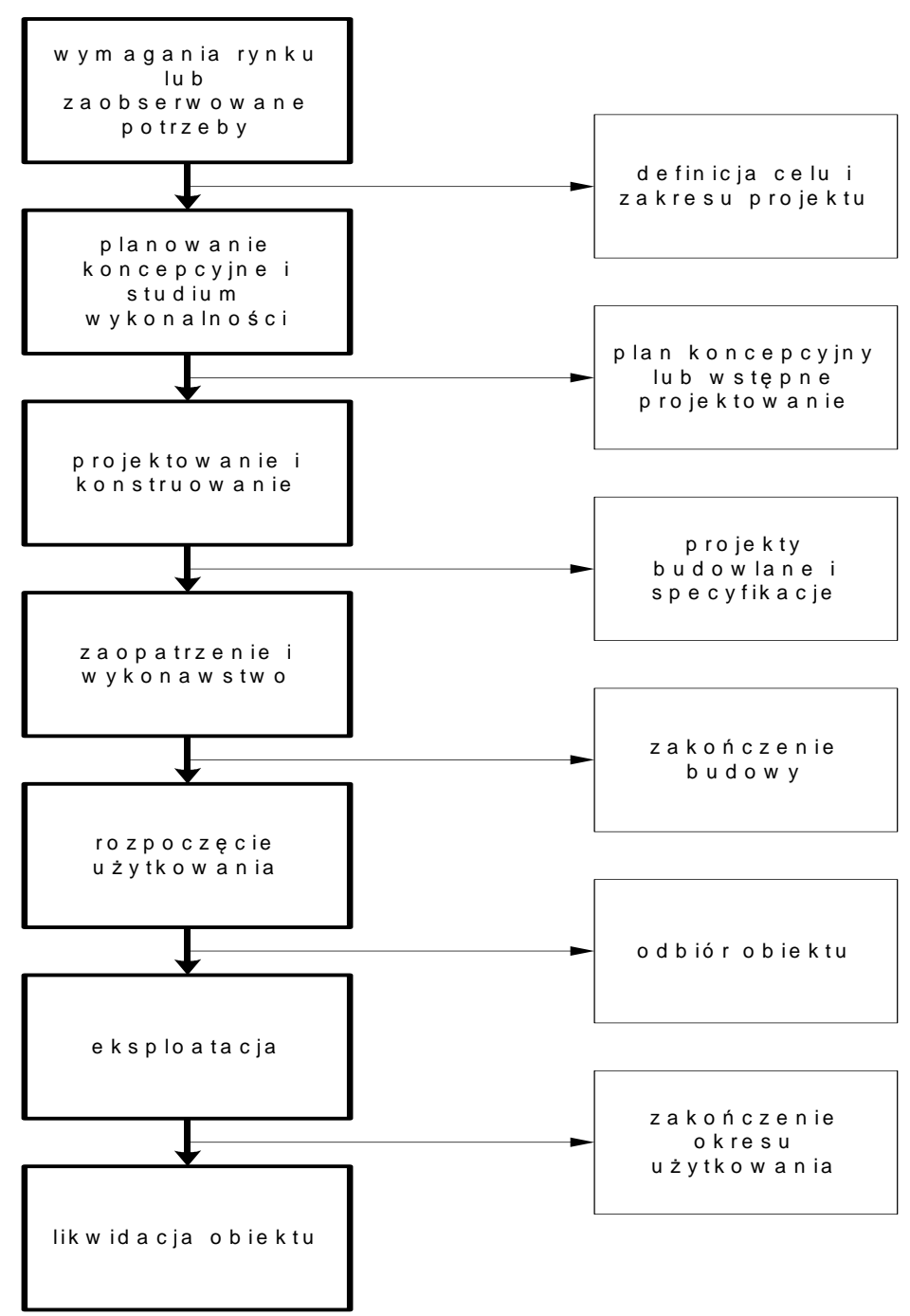

Rys. 1. Cykl życia obiektu budowlanego (opracowano na podstawie [4])

Fig. 1. The life cycle of a building object (based on [4])

Cykl życia obiektu budowlanego, rozpatrywany z perspektywy inwestora, ma szeroki zakres: od powstania zamysłu wzniesienia obiektu budowlanego, poprzez fazę programowania, planowania, organizowania wszystkich procesów budowlanych i ich realizację, aż do fazy eksploatacji oraz likwidacji obiektu. Ta 
perspektywa jest skoncentrowana na obiekcie budowlanym - jako produkcie działalności budowlanej. Trzeba jednak zauważyć, że problemy artykułowane w poszczególnych fazach cyklu życia takich obiektów odnoszą się też do pozostałych interesariuszy projektów. Jednak ich zaangażowanie jest $\mathrm{w}$ znacznej mierze zróżnicowane. Na przykład porównując akcentowanie poziomu istotności problemów, występujących w kolejnych fazach, przez inwestora i wykonawcę prac budowlanych uwidacznia się niemal równomierne traktowanie poszczególnych faz przez inwestora. Natomiast zainteresowaniem wykonawcy cieszy się faza projektowa i realizacyjna wraz z procesami logistycznymi.

\section{Obiekty o konstrukcji stalowej - zagadnienia konstrukcyjno- materiałowe i wznoszenie}

Jak podkreśla Z. Bolkowska [2] najwięcej konstrukcji stalowych stosuje się w budownictwie infrastrukturalnym a zastosowanie ich w budownictwie mieszkaniowym jest minimalne.

Na zalety konstrukcji stalowych składa się szereg właściwości i zalet samego materiału - stali, jak też możliwości konstruowania i wznoszenia obiektów budowlanych. Do głównych można zaliczyć:

- „elastyczność i uniwersalność” w dostosowywaniu się do zmieniających się technologii, możliwość przeprowadzania w łatwy sposób zmian konstrukcyjnych,

- uprzemysłowienie procesu produkcji konstrukcji, skrócenie czasu montażu i możliwość prowadzenia montażu w warunkach zimowych,

- wysoki stopień prefabrykacji, wytwarzanie w warsztacie w postaci elementów, wysyłkowych (przystosowanych gabarytami oraz ciężarem do środków transportu i montażu),

- w nowoczesnych konstrukcjach bardzo niski stopień zużycia stali,

- krótki cykl inwestycyjny,

- ograniczona wielkość placu budowy,

- duży stopień odzysku materiału po zakończeniu eksploatacji,

- możliwość ponownego wykorzystania części konstrukcji (dzięki połączeniom montażowym na śruby),

- duża wytrzymałość oraz jednorodność materiału - wysoka wytrzymałość na ścinanie, ściskanie oraz rozciąganie,

- względna lekkość konstrukcji stalowych (mniejsze koszty transportu oraz montażu).

Syntetyczne ujęcie analizy stosowania konstrukcji stalowych w budownictwie przedstawia tabela 1. Pokazana tam analiza SWOT ukazuje znaczną przewagę czynników pozytywnych nad szkodzącymi. 
Tabela 1. Tabela SWOT stosowania stalowych konstrukcji stalowych (według [6])

Table 1. SWOT table of the use of steel structures (based on [6])

\begin{tabular}{|c|c|}
\hline \multicolumn{2}{|c|}{ Tabela SWOT } \\
\hline Silne strony & Słabe strony \\
\hline $\begin{array}{l}\text { - wysoka wytrzymałość stali na ścinanie, } \\
\text { - względnie niska masa własna, } \\
\text { - lekkość konstrukcji, } \\
\text { - plastyczność stali } \\
\text { - wysoki współczynnik sprężystości } \\
\text { E = 2100000kg/cm², } \\
\text { - jednorodna struktura, } \\
\text { - możliwość użytkowania obiektu budowlanego } \\
\text { zaraz po wykonaniu, } \\
\text { - odporność na działanie sił dynamicznych, } \\
\text { - możliwość przenoszenia znacznych obciążeń } \\
\text { przy względnie małych wymiarach elementów, } \\
\text { - wytrzymałość na rozciąganie, } \\
\text { - elastyczność kształtowania powierzchni, } \\
\text { - możliwość modernizacji stalowego obiektu } \\
\text { budowlanego, } \\
\text { - możliwość odzyskania materiału (ekologiczność), } \\
\text { - możliwość wznoszenia konstrukcji o bardzo } \\
\text { dużych rozpiętościach, } \\
\text { - krótki czas montażu elementów stalowych } \\
\text { (skracanie czasu trwania budowy) }\end{array}$ & $\begin{array}{l}\text { - wrażliwość na korozję, } \\
\text { - odkształcalność stali w ogniu, } \\
\text { - ogniochronność, } \\
\text { - duża przewodność cieplna, } \\
\text { - duża przewodność akustyczna, } \\
\text { - wrażliwość na działanie temperatury, } \\
\text { - konieczność przeprowadzania okreso- } \\
\text { wych konserwacji (podniesienie kosztów } \\
\text { eksploatacji) } \\
\text { - wrażliwość na obciążenia udarowe }\end{array}$ \\
\hline Szanse & Zagrożenia \\
\hline $\begin{array}{l}\text { - wprowadzanie na rynek nowych gatunków stali } \\
\text { o coraz lepszych właściwościach, } \\
\text { - wprowadzanie nowych metod ochrony antykoro- } \\
\text { zyjnej, } \\
\text { - większe zainteresowanie wznoszeniem obiektów } \\
\text { stalowych (zwiększony popyt) }\end{array}$ & $\begin{array}{l}\text { - coraz większa liczba firm zajmujących się } \\
\text { konstrukcjami stalowymi powoduje } \\
\text { wzrost ryzyka obniżenia jakości }\end{array}$ \\
\hline
\end{tabular}

\section{Kryteria oceny jakości technologicznej obiektów o konstrukcji stalowej w cyklu ich życia a interesariusze przedsięwzięć}

Kryteria oceny jakości technologicznej rozwiązań projektowych obiektów budowlanych [3] można generalnie podzielić na: kryteria natury ogólnej, uwzględniające przyjęte rozwiązania konstrukcyjno-materiałowe oraz kryteria szczegółowe odnoszące się do kolejnych faz cyklu życia obiektu budowlanego jako efektu produkcji budowlanej. Problemy ujęte w kryteriach oceny technologiczności mają zmienną siłę oddziaływania na interesy poszczególnych uczestników przedsięwzięcia budowlanego. Wycena kryteriów musi być dokonywana indywidualnie $\mathrm{w}$ perspektywie zainteresowanych podmiotów, np.: inwestorów, projektantów, wykonawców robót budowlanych, dostawców materiałów budowlanych, użytkowników obiektu, społeczności lokalnej, administracji budowlanej. 
Próbę specyfikacji tych kryteriów wraz z uwidocznieniem ich znaczenia dla oceny technologiczności obiektów o konstrukcji stalowej przedstawia tabela 2.

Tabela 2. Kryteria oceny technologiczności obiektów o konstrukcji stalowej

Table 2. Technological quality criteria of steel constructions objects

\begin{tabular}{|c|c|c|c|c|}
\hline Lp. & Kryteria & Opis kryterium & Interesariusze & $\begin{array}{l}\text { Uwagi odnośnie kon- } \\
\text { strukcji stalowych }\end{array}$ \\
\hline \multicolumn{5}{|c|}{ I. Kryteria ogólne } \\
\hline I.1 & \begin{tabular}{|c|} 
rozwiązanie \\
konstrukcyjno- \\
materiałowe \\
\end{tabular} & $\begin{array}{l}\text { rozwiązania mogą być ocenia- } \\
\text { ne z użyciem analizy SWOT }\end{array}$ & $\begin{array}{c}\text { wszyscy uczestnicy przed- } \\
\text { sięwzięcia }\end{array}$ & \begin{tabular}{|c|} 
przewaga pozytywnych \\
stron obiektów o kon- \\
strukcji stalowej \\
\end{tabular} \\
\hline I. 2 & $\begin{array}{l}\text { metoda wzno- } \\
\text { szenia obiektu }\end{array}$ & \begin{tabular}{|c}
$\begin{array}{c}\text { wybór rozwiązań może odnosić } \\
\text { się do stopnia prefabrykacji } \\
\text { konstrukcji }\end{array}$ \\
\end{tabular} & $\begin{array}{c}\text { wszyscy uczestnicy przed- } \\
\text { sięwzięcia }\end{array}$ & $\begin{array}{l}\text { konstrukcje stalowe są } \\
\text { zwykle prefabrykowane }\end{array}$ \\
\hline \multicolumn{5}{|c|}{ II. Kryteria szczegółowe } \\
\hline II. 1 & $\begin{array}{l}\text { sformułowane } \\
\text { potrzeby bu- } \\
\text { dowlane }\end{array}$ & $\begin{array}{l}\text { w toku formułowania tego } \\
\text { kryterium pojawiają się prze- } \\
\text { słanki do wyboru rozwiązania } \\
\text { konstrukcyjno-materiałowego }\end{array}$ & $\begin{array}{l}\text { inwestorzy, projektanci, } \\
\text { użytkownicy obiektu, } \\
\text { społeczność lokalna, } \\
\text { administracja budowlana }\end{array}$ & $\begin{array}{c}\text { konstrukcje stalowe dają } \\
\text { szersze możliwości } \\
\text { kształtowania zabudowy } \\
\text { przestrzeni }\end{array}$ \\
\hline II. 2 & $\begin{array}{c}\text { koncepcja i } \\
\text { studium wyko- } \\
\text { nalności }\end{array}$ & $\begin{array}{c}\text { doprecyzowanie rozwiązania } \\
\text { obiektu, studium wykonalności } \\
\text { winno sygnalizować problemy } \\
\text { w obrębie całego cyklu życia } \\
\text { obiektu }\end{array}$ & $\begin{array}{l}\text { inwestorzy, projektanci, } \\
\text { użytkownicy obiektu, } \\
\text { społeczność lokalna, } \\
\text { administracja budowlana }\end{array}$ & $\begin{array}{l}\text { konstrukcje stalowe dają } \\
\text { możliwości przewidywa- } \\
\text { nia parametrów wytrzy- } \\
\text { małościowych na wyso- } \\
\text { kim poziomie ufności }\end{array}$ \\
\hline II. 3 & $\begin{array}{c}\text { projekt obiektu i } \\
\text { procesów } \\
\text { budowlanych }\end{array} \mid$ & $\begin{array}{l}\text { rozwiązania funkcjonalno- } \\
\text { użytkowe, metody i techniki } \\
\text { realizacyjne }\end{array}$ & $\begin{array}{l}\text { wszyscy uczestnicy } \\
\text { przedsięwzięcia }\end{array}$ & $\begin{array}{c}\text { konstrukcje stalowe dają } \\
\text { możliwość elastycznego } \\
\text { zagospodarowania } \\
\text { przestrzeni }\end{array}$ \\
\hline II. 4 & $\begin{array}{l}\text { procesy logi- } \\
\text { styczne }\end{array}$ & $\begin{array}{c}\text { szczegóły logistyczne obejmu- } \\
\text { jące rozwiązania dostaw zaso- } \\
\text { bów, w tym środki transportu, } \\
\text { drogi przemieszczania i miej- } \\
\text { sca dostarczania }\end{array}$ & $\begin{array}{l}\text { inwestorzy, projektanci, } \\
\text { wykonawcy robót budow- } \\
\text { lanych, dostawcy materia- } \\
\text { łów budowlanych, spo- } \\
\text { łeczność lokalna, admini- } \\
\text { stracja budowlana }\end{array}$ & $\begin{array}{c}\text { prefabrykaty konstrukcji } \\
\text { stalowych mogą być } \\
\text { wytwarzane u wyko- } \\
\text { nawcy robót lub w } \\
\text { innych zakładach co } \\
\text { uelastycznia procesy } \\
\text { logistyczne }\end{array}$ \\
\hline II.5 & $\begin{array}{c}\text { procesy budow- } \\
\text { lane }\end{array}$ & $\begin{array}{l}\text { przedstawienie wariantów } \\
\text { technologiczno- } \\
\text { organizacyjnych }\end{array}$ & $\begin{array}{l}\text { inwestorzy, projektanci, } \\
\text { wykonawcy robót budow- } \\
\text { lanych, dostawcy materia- } \\
\text { łów budowlanych, spo- } \\
\text { łeczność lokalna, admini- } \\
\text { stracja budowlana }\end{array}$ & $\begin{array}{c}\text { organizacja montażu } \\
\text { konstrukcji stalowych } \\
\text { może przewidywać } \\
\text { montaż ze składowisk } \\
\text { przyobiektowych lub } \\
\text { według metody ,,just in } \\
\text { time" }\end{array}$ \\
\hline II.6 & eksploatacja & $\begin{array}{c}\text { problemy bezpiecznej eksploa- } \\
\text { tacji obiektu, utrzymanie } \\
\text { obiektu w stanie pełnej uży- } \\
\text { teczności, zasady kontroli stanu } \\
\text { technicznego }\end{array}$ & $\begin{array}{c}\text { inwestorzy, projektanci, } \\
\text { wykonawcy robót budow- } \\
\text { lanych, dostawcy materia- } \\
\text { łów budowlanych, użyt- } \\
\text { kownicy obiektu, społecz- } \\
\text { ność lokalna, administracja } \\
\text { budowlana }\end{array}$ & $\begin{array}{l}\text { potrzeba skupienia } \\
\text { uwagi na zabezpiecze- } \\
\text { niach antykorozyjnych } \\
\text { konstrukcji stalowych }\end{array}$ \\
\hline II.7 & likwidacja & $\begin{array}{l}\text { metody prac rozbiórkowych, } \\
\text { odzysk materiałów, problemy } \\
\text { bezpieczeństwa przy rozbiórce }\end{array}$ & $\begin{array}{l}\text { inwestorzy, projektanci, } \\
\text { społeczność lokalna, } \\
\text { administracja budowlana }\end{array}$ & $\begin{array}{c}\text { konstrukcje stalowe } \\
\text { mają w fazie likwidacji } \\
\text { wysoką jakość ekolo- } \\
\text { giczną }\end{array}$ \\
\hline
\end{tabular}




\section{Podsumowanie}

Rozważanie problemów jakości technologicznej rozwiązań projektowych winno uwzględniać kryteria ogólne, opisujące cechy charakterystyczne dla danego typu konstrukcji, interesujące wszystkich uczestników przedsięwzięcia. Natomiast szereg kryteriów szczegółowych, odnoszących się do poszczególnych faz życia obiektu budowlanego, trzeba rozważać indywidualnie z perspektywy konkretnego interesariusza projektu.

Analiza technologiczności rozwiązań projektowych, pozwala poszczególnym interesariuszom na wykorzystanie oceny jakości technologicznej obiektów w podejmowaniu decyzji o wyborze rozwiązań projektowych (np. przez inwestora), czy o zaangażowaniu się w dane przedsięwzięcia budowlane (np. przez wykonawcę zadań budowlanych).

W ocenie technologiczności, w zależności od rozważanego podmiotu, zróżnicowany może być dobór kryteriów szczegółowych, jak też wagi przypisane poszczególnym kryteriom, wycenianym według wybranych zasad parametryzacji, np. w przyjętej skali punktowej.

\section{Literatura}

[1] Augustyn J., Śledziewski E.: Technologiczność konstrukcji stalowych, Arkady, Warszawa 1981.

[2] Bolkowska Z.: Budownictwo i konstrukcje stalowe u progu nowej perspektywy finansowej UE (2014-2020), Konstrukcje stalowe, nr 3, 2014, s. 8-10.

[3] Czemplik A., Irzyk M.: Ocena technologiczności projektów budowlanych, Wydawnictwo Politechniki Białostockiej, Civil and Environmental Engineering (Budownictwo i Inżynieria Środowiska), nr 2, 2011, s. 225-228.

[4] Hendrickson Ch.: Project Management for Construction. Fundamental Concepts for Owners, Engineers, Architects and Builders, Department of Civil and Environmental Engineering, Carnegie Mellon University, Pittsburgh 2003.

[5] Jaworski K.M.: Metodologia projektowania realizacji budowy, Polskie Wydawnictwo Naukowe, Warszawa 2009.

[6] Michalska A.: Analiza szans i zagrożeń stosowania konstrukcji stalowych w budownictwie na wybranym przykładzie, Praca magisterska napisana pod kierunkiem J. Bizon-Góreckiej, WBAiIŚ UTP w Bydgoszczy, Bydgoszcz 2016.

[7] Sadowski Z.: Technologiczność prefabrykowanych konstrukcji żelbetowych, Arkady, Warszawa 1983.

\section{MANUFACTURABILITY ANALYSIS OF STEEL STRUCTURES}

\section{S u m m a r y}

A purpose of the article is to point out a possibility of assessing the quality of construction and material solutions by analyzing their manufacturability, understood as a technological quality. A concept of manufacturability of buildings is defined as an adaptation of the solutions to get 
an easy and economically viable performance, ensuring a fulfillment of all requirements imposed on a building throughout its life cycle. An objective and needs are identified in the beginning of the building life cycle of the construction. Then there is a conceptual design and a feasibility study followed by a detailed design and creating a documentation. After that there are construction processes along with construction logistics and building commissioning in the end. Next an operation and a maintenance are followed by a demolition. It was made an attempt to specify some factors of assessing the technological quality of steel frame buildings especially in each phase of the building life cycle. Studies were carried out on the basis of the available literature and practical experience of the authors. It was indicated that a need for considering the construction and material solutions is very important. A so-far-neglected need for taking into consideration a stakeholder perspective in a manufacturability assessment was emphasized in the article. It results from some specific requirements of the building given by project stakeholders. Due to the fact that shaping an object in a concept-design-construction phase is related to building operations-maintenancedemolition phase, each stakeholder should consider all stages of the building life cycle.

Keywords: steel structures, technological quality, life cycle

Przestano do redakcji: 6.02 .2017 r.

Przyjęto do druku: $30.06 .2017 \mathrm{r}$. 